3. Stocking B. Promoting change in clinical care, Quarterly in Health Care 1992, 1, 56-60.

4. Davies PT. Changing policy and practice. In Dawes MG, Davies PT, Gray A, Mant J, Seers K, editors. Evidence-based practice: A primer for health professionals, $2^{\text {nd }}$ edition, London, Churchill Livingstone, 2004.

5. Davies PT. Is evidence-based government possible? Jerry Lee Lecture, $4^{\text {th }}$ Campbell Colloquium, Washington D.C.
19 February 2004. Available at www.policyhub.gov.uk/ news_item/jerryleelecture1202041.pdf. Accessed 22 February 2006.

6. Canadian Health Services Research Foundation. Readerfriendly writing-1:3:25, Communication Notes, Ottawa, Canadian Health Services Research Foundation, 2001. Available at: www.chsrf.ca/knowledge_transfer/pdf/cn1325_e.pdf. Accessed 22 February 2006. 중

\title{
WHAT EVIDENCE INFORMS GOVERNMENT POPULATION HEALTH POLICY? LESSONS FROM EARLY CHILDHOOD INTERVENTION POLICY IN AUSTRALIA
}

\section{Shelley Bowen \\ PhD candidate \\ University of NSW}

\section{Anthony Zwi}

School of Public Health and Community Medicine

University of NSW

\section{Peter Sainsbury}

Population Health

Community Health

Sydney South West Area Health Service

Given that we know that policy making is iterative, continuous, incremental, subject to review and inherently political' ${ }^{1}$, how does evidence feed into policy?

The term 'evidence-based policy' has become routinely used in government policy deliberations, but the rhetoric is often not matched by the reality. The systematic integration of evidence into policy and practice is rare. There is also ongoing debate on what constitutes evidence for policy. This paper proposes a way of categorizing, according to source, the evidence used for policy making. We draw on the literature and on the ideas and experiences of the key people (referred to here as policy 'actors') involved in the development of policies that support families and the early years of life in NSW and South Australia. The findings from this study suggest that a variety of types of evidence inform health policy making. This challenges the public health community to broaden its ideas on what constitutes evidence for policy and to recognize the validity of different types of evidence in better informing the policy process.

Policy making is complex; appreciating the interplay of people, processes and politics is critical if such processes are to be understood. While policy actors are constantly encouraged to base their policy making on evidence, this is extremely difficult given the limited quality of available policy-relevant research to inform the breadth of public health issues. One response to navigating the use of evidence in policy making is to adopt an 'evidenceinformed' approach ${ }^{2}$ that considers how different types of information may be transformed into evidence for policy making. We seek not to detract from the value of high quality research evidence, but rather to recognize that even when such evidence is available, governments still draw on a variety of other forms of evidence to more comprehensively inform their decisions.

\section{HOW ARE EVIDENCE AND POLICY MAKING LINKED?}

The evidence movement has its origins in evidence-based medicine, 'the conscientious, explicit and judicious use of current best evidence in making decisions about the care of individual patients'. ${ }^{3}$ However, the public health community has been struggling with attempts to transfer the concept of evidence-based medicine to policy and practice. ${ }^{4,5}$ Recent literature has transformed the notion of evidence from clinical interventions and direct pathways to practice to evidence in complex policy settings in which people, processes and politics need be considered..$^{2,6-9}$ The term 'evidence-based decision making' has emerged to describe the use of the best possible evidence when dealing with real life circumstances..$^{3,10-12}$

Rychetnik and colleagues (2004) encourage the judicious use of a range of research and evaluation evidence. ${ }^{9,13}$ There is increasing recognition of complementary and competing evidence in the policy process, building on scientific research ${ }^{3,10,14-18}$, although health policy decisions remain primarily based on experience and opinion, with little use of available research evidence. ${ }^{18-23}$ Davies et al ${ }^{24}$ describe the 'hot debate' raging around definition and propose that the term 'evidence influenced practice' would emphasise the need to be context sensitive, examining what works and in what context. 
The UK Cabinet Office propose that expert knowledge, existing domestic and international research, available statistics, stakeholder consultation, evaluation of previous policies, new research, and secondary analyses, inform policy development. ${ }^{12,15}$ This suggests that evidence is data that can be turned into information and may be sourced from a variety of areas. ${ }^{25}$

The aim of this paper is to use the experiences of views of policy makers to categorise the forms of evidence used in the policy making process.

\section{METHODOLOGY}

Building on concepts from the literature, this paper also draws on 35 semi-structured, in-depth interviews with policy actors in South Australia $(n=10)$ and NSW $(n=25)$ over 2004 and 2005. Interviewees were selected on the basis of their involvement in committees, roles in policy and government, authorship of grey and published literature, identification on relevant web sites, reference in the media and through 'snowballing' during an initial round of interviews. Interviewees included politicians, political advisors, researchers, journalists and a range of public servants at various levels in government departments and regional health services.

Interview questions focussed on:

- when and why the policy area becomes important

- what sorts of information inform policy

- what 'evidence' means in this policy area

- what evidence is useful to the policy process and when

- what drives policy: evidence, equity or something else?

- interests of decision-makers: is it in evidence of what works or evidence that describes a problem?

\section{EVIDENCE IN EARLY YEARS POLICIES}

In recent years there has been significant policy investment in prevention and early intervention strategies with families in NSW and South Australia. Families First NSW and Every Chance for Every Child, South Australia, emerged as whole-of-government approaches to providing children with a good start in life. One strategy within these policies is supporting mothers and new babies through nurse home visiting. Delivery of nurse home visiting differs in the two states. NSW offers a universal first home visit to all new mothers and their babies. In South Australia, a universal first visit is offered as well as sustained regular home visiting over a two-year period to those most in need.

These programs have been heralded throughout their development as equity promoting, solution focused and evidence based. ${ }^{26,27}$ Policies that focus on early childhood intervention with parents and young babies provide a powerful opportunity for public health improvement and impact on lifelong health and other positive social outcomes for children. These two policies were selected for study as they provide critical insights into health policy development and the role of evidence.

\section{FINDINGS FROM INTERVIEWS: WHAT DID POLICY ACTORS SAY ABOUT THE EVIDENCE?}

The term 'evidence' can mean many things to many people: 'is it information from a trial or something we did yesterday?' asked one informant. There appear to be two views on the nature of evidence: many believe that 'evidence' implies research while others acknowledge that in policy decision-making, research evidence is complemented by a breadth of information which includes, but is not restricted, to research.

Interviewees described 'hard' and 'strong' forms of research evidence, with hard evidence measured by randomised controlled trials (RCTs) or other forms of rigorous studies (Box 1). Different research evidence was sought for four distinct purposes in the development of these policies: evidence of the problem, evidence of effectiveness, evidence of effective implementation and evidence of cost effectiveness (Box 2). The 'hard and visible science' of brain development largely generated by Dr Bruce Perry ${ }^{28}$ from the United States was a particularly influential piece of evidence informing early years policy development. Policy actors described this evidence as symbolic in its graphic display of brain size in nurtured and neglected babies. A source of intervention evidence was a 15-year RCT by Olds and colleagues of the long-term effects of home visiting on child abuse and neglect. ${ }^{29}$

A second source of intervention evidence is the Perry preschool studies in the United States. These studies followed the lives of 123 poor African American children

\section{BOX 1}

\section{RESEARCH AS THE ONLY LEGITIMATE SOURCE OF EVIDENCE: QUOTES FROM INTERVIEWS WITH POLICY ACTORS, NSW AND SOUTH AUSTRALIA, 2004-2005}

'you know hard evidence, if you like, would be studies that have a before and after. They have a control group and they have multiple sites'

'it [evidence] is the empirical science of brain development'

'the strongest evidence from the literature was home visiting by nurses'

'Evidence is an RCT'

'it [evidence] is randomised controlled studies'

'the two key bits of evidence were the brain development stuff, and the appreciation of the importance of the early years and its impact on the rest of your life' 
BOX 2

\section{EXAMPLES OF EVIDENCE THAT INFORMED EARLY YEARS POLICY DEVELOPMENT IN AUSTRALIA}

\begin{tabular}{|c|c|}
\hline Purpose of evidence & Source of evidence \\
\hline $\begin{array}{l}\text { What's the problem evidence } \\
\text { (descriptive) }\end{array}$ & $\begin{array}{l}\text { Observational data: Presentation of impact on child (neuro) development of abuse by Dr Bruce } \\
\text { Perry* }\end{array}$ \\
\hline $\begin{array}{l}\text { What works evidence } \\
\text { (intervention) }\end{array}$ & $\begin{array}{l}\text { Published study/reports: Perry Preschool (Highscope) project in the United States-30 year follow } \\
\text { up }(1993)^{31} ; 40 \text { year follow }(2005)^{30} \\
\text { Published study: Long term effects of home visitation on maternal life course and child abuse and } \\
\text { neglect: fifteen year follow up of a randomised control trial, David Olds et al, JAMA - }(1997)^{29}\end{array}$ \\
\hline $\begin{array}{l}\text { How it works evidence } \\
\text { (implementation) }\end{array}$ & Some insights in Olds ${ }^{29}$, RAND Corporation report ${ }^{32}$ and the Perry Preschool study ${ }^{31}$ \\
\hline $\begin{array}{l}\text { What it costs evidence } \\
\text { (economic) }\end{array}$ & $\begin{array}{l}\text { Discussion paper: Costing home visiting for NSW; NSW Health (1998) }{ }^{27} \\
\text { Report: RAND Corporation in the United States- } \$ 1 \text { spent }=\$ 7+\text { saved }^{32}\end{array}$ \\
\hline
\end{tabular}

for up to 40 years and measured the effects of a high quality preschool education program on school failure and associated problems. ${ }^{30,31}$ Synthesis of the evidence on these and other intervention studies formed the base for reports that demonstrate cost effectiveness of investing in nurse home visiting. The economic benefits of early

\section{BOX 3}

\section{USING A BREADTH OF SOURCES OF EVIDENCE: QUOTES FROM INTERVIEWS WITH POLICY} ACTORS, NSW AND SOUTH AUSTRALIA, 2004-2005

'The other sort of evidence is empirical evidence about what people think, about community polling or public surveys and things like that'

'A combination of things, anecdotal, wisdom, cross sectional studies, RCTs etcetera. It is a full continuum of information'

'Well it's not level 1 RCT evidence'

'we started pulling in all of the overseas evidence about programs and things around Australia...We said alright these are all of the different levels and examples of evidence'

'it's some sort of empirical observation or set of empirical observations or modeling of possible and probable empirical outcomes'

'General literature, studies all the sorts of things you usually use in a literature review including grey literature, trials, studies etcetera, to small pilot type studies'

'Informal interviews with colleagues in other states formed the evidence for this policy'

'The other piece of evidence was the US government accounting for its review of the economic benefits of early intervention prevention'

'all of these people feed information, both experiential and research level' intervention are found in the Rand Corporation report in the United States. ${ }^{32}$ A NSW Health discussion paper ${ }^{27}$ modeled the actual costs associated with delivery of nurse home visiting programs statewide. The critical 'how it can be done' evidence to guide effective implementation is a gap in these policy examples, as little is known and almost nothing published on what actually occurs during home visits by nurses.

Policy actors also identified a breadth of evidence relevant to policy context (Box 3). Such insights derive from sources ranging from clinical trials to experiences and knowledge of what people think, whether determined informally or through community polling and surveys. A 'full continuum of information' was proposed as critical to policy making by one participant, and should include the sciences, experience and opinion. The experience of other programs was considered key to informing policy making. These experiences may come from individuals or via reports, the 'grey literature', not necessarily evaluated sources. In contrast to the comment that 'evidence is an RCT', others stated that evidence is not 'level 1 RCT evidence' for policy making. Clearly those involved in policy making have different views, equally strongly held, about the nature of evidence.

\section{OUR SYNTHESIS: A WAY OF UNDERSTANDING EVIDENCE FOR POLICY MAKING}

There are many ideas concerning what constitutes evidence in the policy environment, the answer being dependant upon the question being asked. Evidence of the impact of a clinical intervention will involve something very different to the evidence for effective interventions by health professionals in the home with families. An RCT may be a reasonable method for one whereas qualitative methods may be required for the other. ${ }^{33,34}$ Review of the literature and the findings from this study support the idea of evidence-informed policy making which 'sees the use of different types of information in a variety of forms and 


\section{FIGURE 1}

\section{TYPES OF 'EVIDENCE' INFORMING THE POLICY PROCESS}

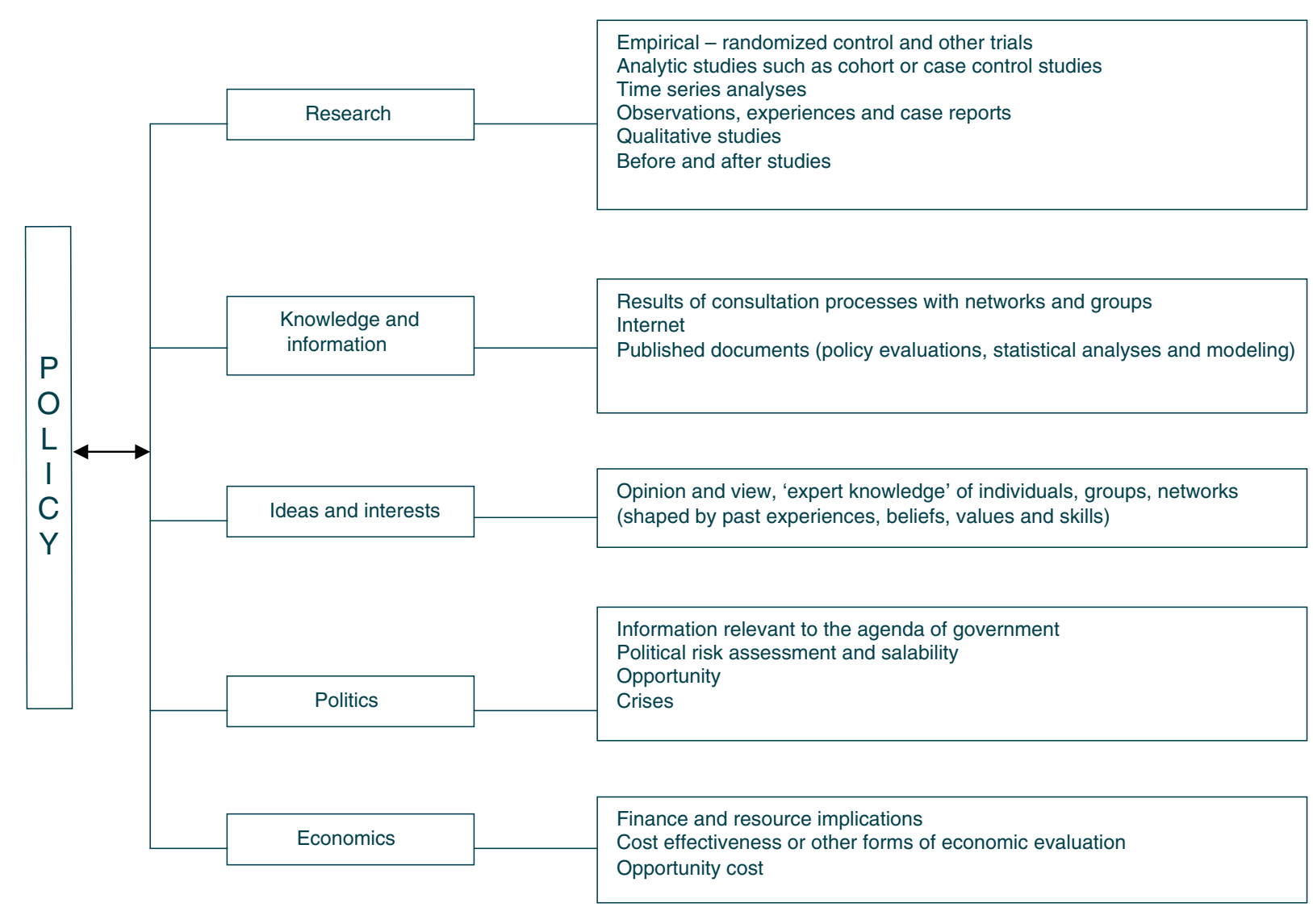

from a variety of sources, reflective of and responsive to, the policy and practice context'. ${ }^{2}$

We can discern at least five types of information that inform policy development: research, knowledge, ideas and interests, politics, and economics (Figure 1). Can all or some of these types of information be called evidence for policy?

This model describes the forms of information and influences on policy making. Do we name these non-research types of information 'evidence'? Is scientific research the only form of evidence that has a rightful place as the basis of the policy process? What definition of evidence best serves policy? If we continue with the idea that scientific research, 'hard evidence', is the only appropriate form of evidence, then 'evidence-based policy' is seldom achievable. And while the other four types of evidence are at risk of being ignored by researchers and policy analysts, these are in reality drawn upon for decision-making and often have greatest impact on real-life decisions.

If we recognise that a breadth of evidence informs policy making, then this should affect how we approach the production and use of such evidence. Irrespective of the source of the evidence-for example political or policy science, or economics, RCT or focus group discussionthe pursuit of the highest quality and most robust evidence is essential.

This model aims to identify the information sources in public health policy making. It helps determine areas where we could be building the evidence base for making decisions. It will not, however, tell us which of these forms of evidence is most important, or how to weight them in one or other contexts; this warrants further work.

\section{CONCLUSION}

The views of policy actors in Australia exposed different understandings of the nature and use of 'evidence' for policy. These findings resonate those from the United Kingdom and Canada. ${ }^{12,33}$ Drawing on these views and the literature, we have developed a model to help navigate the development and use of evidence in policy making. This synthesis demonstrated that a variety of types of evidence inform policy making. Considering evidence to be derived from research, knowledge, interests and ideas, political and economic information challenges us to commission, produce, sharpen and use a variety of sources, forms and formats of evidence in policy making. 


\section{REFERENCES}

1. Lin V, Gibson B. Evidence-based health policy: Problems and possibilities. South Melbourne: Oxford University Press, 2003.

2. Bowen S, Zwi A. Pathways to "Evidence-informed" policy and practice: A framework for action. PLoS Medicine 2005; 2: 106-11.

3. Sackett DL, Rosenberg WMC, Muir Gray JA, Haynes RB, Richardson WS. Evidence based medicine: What it is and what it isn't. Br Med J 1996; 312: 71-2.

4. Newman K, Pyne T, Leigh S, Rounce K, Cowling A. Personal and organizational competencies requisite for the adoption and implementation of evidence-based healthcare. Health Services Management Research 2000; 13: 97-110.

5. Niessen LW, Grijseels EWM, Rutten FFH. The evidencebased approach in health policy and health care delivery. Soc Sci Med 2000; 51: 859-69.

6. Kingdon JW. Agendas, alternatives and public policy. New York: NY: Harper Collins, 1995.

7. Dobbins M, Ciliska D, Cockerill R, Barnsley J, DiCenso A. A framework for the dissemination and utilization of research for health-care policy and practice. Online Journal for Knowledge Synthesis for Nursing 2002; Nov 18: 9; 7: 606-10.

8. Shaxson L. Is your evidence robust enough? Questions for policy makers and practitioners. Evidence and Policy 2005; 1: 101-11.

9. Rychetnik L, Hawe P, Waters.E, Barratt A, Frommer M. A glossary for evidence based public health. J.Epidemiol Community Health 2004; 58: 538-45.

10. Nutbeam D. Evidence based, public policy for health: matching research to policy need. Evidence 1996.

11. Nutbeam D. Improving the fit between research and practice in health promotion: Overcoming structural barriers. Can J Public Health 1996; 87: 18-23.

12. Davies P. Is evidence-based government possible? 19 February 2004. Washington DC, 4th Annual Campbell Collaboration Colloquium.

13. Frommer M, Rychetnik L. From evidence-based medicine to evidence-based public health. In Lin V, Gibson B, eds. Evidence-based health policy: Problems and possibilities. Melbourne: Oxford University Press, 2003: 56-69.

14. Mays N, Pope C, Popay J. Systematically reviewing qualitative and quantitative evidence to inform management and policy making in the health field. J Health Serv Res Policy 2005; 10: S1:6-S1:20.

15. The Cabinet Office. Professional policy making for the 21st century. London, The Cabinet Office, 1999.

16. Elliot H, Popay J. How are policy makers using evidence? Models of research utilisation and local NHS policy making. Journal of Epidemiology and Community Health 2000; 54, 461-8.

17. Hayward S, Ciliska D, DiCenso A, Thomas H, Underwood EJ, Rafael A. Evaluation research in public health: barriers to the production and dissemination of outcomes data. Can J Public Health 1996; 87: 413-7.

18. Black N. Evidence based policy: proceed with care. $\mathrm{Br}$ Med J 2001; 323: 275-9.
19. Baessler CA, Blumberg M, Cunningham JS. Medicalsurgical nurses' utilization of research methods and products. Medsurgical Nursing 1994; 3: 113-21.

20. Pappaioanou M, Malison M, Wilkins K, Otto B, Goodman RA, Churchill RE et al. Strengthening capacity in developing countries for evidence-based public health: the data for decision-making project. Soc Sci Med 2003; 57: 1925-37.

21. Bohannon RW,.LeVeau BF. Clinicians' use of research findings: A review of literature with implications for physical therapists. Physical Therapy 1986; 66: 45-50.

22. Luker KA, Kendick M. An exploratory study of the sources of influence on the clinical decisions of community nurses. Journal of Advanced Nursing 1992; 17: 457-66.

23. Nutbeam D. How does evidence influence public health policy? Tackling health inequalities in England. Health Promot J Austr 2003; 14: 154-8.

24. Davies H, Nutley S, Smith P. What works? Evidence-based policy \& practice in public services. Bristol. Bristol: Policy Press, 2000.

25. Bardach E. A practical guide for policy analysis: the eightfold path to more effective problem solving. New York: Seven Bridges Press, 2000.

26. Department of Human Services. Early childhood services initiative: sustained home visiting program model. South Australia, Department of Human Services, 2003.

27. Wraith C, Kakakios M, Alperstein G, Nossar V, Wolfenden S. Achieving health outcomes for children in NSWStrengthening families and communities. Sydney: NSW Health, 1998.

28. Perry BD, Pollard R, Blakely T et al. Childhood trauma, the neuro-biology of adaptation and use-dependent development of the brain: How states become traits. Infant Mental Health Journal 1995; 16: 271-9.

29. Olds DL, Eckenrode J, Henderson CR, Kitzman H, Powers J, Cole $\mathrm{R}$ et al. Long term effects of home visitation on maternal life course and child abuse and neglect: Fifteen year follow up of a randomised control trial. JAMA 1997; 278: 637-43.

30. Schweinhart L, J Montie J, Xiang Z, Barnett W S, Belfield C R, Nores M. Lifetime effects: The High/Scope Perry preschool study through age 40 (monographs of the High/ Scope Education Research Foundation, 14). Ypsilanti, MI: High/Scope Press, 2005.

31. Schweinhart L, J, Barnes HV, Weikart DP. Significant benefits: The High/Scope Perry preschool study through age 27 (monographs of the High/Scope Education Research Foundation, 10). Ypsilanti, High/Scope Press, 1993.

32. Karoly L, Greenwood PW, Everingham SS, Hoube J, Kilburn MR, Rydell et al. Investing in our children: What we know and don't know about the costs and benefits of early childhood intervention. Santa Monica: Rand Corporation, 1998.

33. Lomas J, Culyer T, McCutcheon, McCauley L, Law S. Conceptualizing and combining evidence for health system guidance. Canadian Health Services Research Foundation, 2005: 1-43.

34. Penn et al. Our synthesis: a way of understanding evidence for policy making. London: Government Social Research Unit, 2005. 